\title{
PENGARUH PERAN KEPEMIMPINAN DAN KERJASAMA TIM TERHADAP KINERJA PEGAWAI PADA BADAN KEPEGAWAIAN DAERAH KOTA PEMATANGSIANTAR
}

\author{
Oleh: \\ Lamtiur Simanjuntak \\ S1 Manajemen \\ Darwin Lie, Efendi, Ady Irawan
}

Abstraksi

Adapun tujuan penelitian ini adalah: 1. Untuk mengetahui gambaran peran kepemimpinan dan kerjasama tim terhadap kinerja pegawai pada BKD Kota Pematangsiantar. 2. Untuk mengetahui pengaruh peran kepemimpinan dan kerjasama tim terhadap kinerja pegawai pada BKD Kota Pematangsiantar.

Penelitian ini dilakukan dengan menggunakan desain penelitian lapangan dan kepustakaan. Sedangkan jenis data yang digunakan yaitu data kualitatif dan data kuantitatif, lalu menggunakan data primer dan data sekunder. Adapun populasi yang digunakan penulis dalam penelitian ini adalah sebanyak 43 responden yaitu pegawai pada BKD Kota Pematangsiantar. Pengumpulan data dilakukan dengan kuesioner, wawancara, dokumentasi dan observasi. Teknik analisis yang digunakan ialah regresi linier berganda, koefisien korelasi dan determinasi serta pengujian hipotesis dengan uji $\mathrm{t}$ dan uji $\mathrm{F}$.

Hasil penelitian dapat disimpulkan sebagai berikut: 1. Pegawai menyatakan bahwa peran kepemimpinan, kerjasama tim serta kinerja pegawai baik. 2. Hasil analisis regresi adalah $\hat{Y}=24,495+0,395 X_{1}+$ $0,991 \mathrm{X}_{2}$, artinya peran kepemimpinan dan kerjasama tim berpengaruh positif terhadap kinerja pegawai. 3. Hasil analisis korelasi diperoleh nilai $\mathrm{r}=0,793$ artinya terdapat hubungan yang kuat dan positif antara peran kepemimpinan dan kerjasama tim dengan kinerja pegawai. Koefisien Determinasi tinggi rendahnya kinerja pegawai dapat dijelaskan oleh peran kepemimpinan dan kerjasama tim sebesar $62,8 \%$ sedangkan sisanya sebesar $37,2 \%$ dipengaruhi oleh faktor lain seperti motivasi, kompetensi, kompensasi, pengembangan karir, dan dukungan manajemen. 4. Hipotesis penelitian $\mathrm{H}_{0}$ ditolak, artinya peran kepemimpinan dan kerjasama tim berpengaruh positif dan signifikan terhadap kinerja pegawai pada BKD Kota Pematangsiantar baik secara simultan maupun parsial.

Adapun saran dari penelitian ini adalah untuk meningkatkan peran kepemimpinan dalam organisasi maka seorang pimpinan perlu mempererat hubungan kekeluargaan dengan para pegawai melalui terlebih dahulu mengenal baik setiap pegawai. Untuk meningkatkan kerjasama tim maka pimpinan perlu melakukan komunikasi yang baik oleh pimpinan kepada pegawai, seperti memberi kesempatan kepada pegawai untuk menyampaikan pernyataannya.

Kata Kunci: Peran Kepemimpinan, Kerjasama Tim dan Kinerja Pegawai

\section{Abstraction}

As for the purpose of this research is: 1. To know the description of leadership role and teamwork of the employees performance at BKD Kota Pematangsiantar. 2. To know the influence of leadership and teamwork of employees performance at $\mathrm{BKD}$ Kota Pematangsiantar.

This research was done with field research design and library research. As for the population used by the author in this research is as much as 43 correspondents, that is employees at BKD Kota Pematangsiantar. The data collection was done with questionnaire, interview, documentation and observation. The analysis technique used in this research was multiple liniar regression, correlation coefficient and determination as well as the test of hyphothesis with $t$ test and $F$ test.

The results of the study can be summarized as follows: 1. Employees stated that leadership in this company is high, teamwork and employees performance in this company is good. 2. The analysis regression is $\hat{Y}$ $=24,495+0,395 X_{1}+0,991 X_{2}$, means that leadership and teamwork has good effect to employees performance.3. Analysis correlation obtained $r$ value $=0,793$, means that there is moderately high and positive correlation between leadership and teamwork with employees performance. High low employees performance can be explained by leadership and teamwork amounting to 62,8\% while the rest is 37,2,0\% affected by other factor like motivation, competence, compensation, carrier development and management support. 4. The research hyphothesis of $H_{0}$ is rejected, means that leadership and teamwork simultaneously have positive affect and significant to employees performance at BKD Kota Pematangsiantar.

The suggestion from this research is to the improve of have care about the work of employees performance leadership The need to strengthen kinship ties with employees through first familiar to every employee. To improve teamwork then the leadership needs to make good communication by the leadership to employees, such as giving an opportunity to the employee to convey his statement. 


\section{A. PENDAhuluan}

\section{Latar Belakang Masalah}

Badan Kepegawaian Daerah (BKD) merupakan sebuah instansi pemerintah yang mempunyai tugas melaksanakan penyusunan dan pelaksanaan kebijakan daerah di bidang kepegawaian. Dalam hal ini (BKD) Kota Pematangsiantar adalah unsur pendukung dalam membantu tugas Walikota selaku Wakil Pemerintah dalam melaksanakan Manajemen Pegawai Negeri Sipil Daerah dibidang Kepegawaian, yang dipimpin oleh kepala Badan yang bertanggungjawab kepada Walikota melalui Sekretaris Daerah. Untuk melaksanakan tugas dan fungsi sebagai Pembina Kepegawaian yang merupakan unsur pendukung tugas Walikota Pematangsiantar, tentunya diharapkan memiliki pegawai yang memiliki kinerja optimal.

Kinerja merupakan hasil kerja yang dapat dicapai pegawai, sesuai dengan tugas dan wewenang masing-masing dalam rangka mencapai tujuan organisasi. Adapun kinerja pegawai pada BKD Kota Pematangsiantar dinilai berdasarkan Peraturan Pemerintah Nomor 46 Tahun 2011 dan Peraturan Kepala Badan Kepegawaian Daerah Kota Pematangsiantar Nomor 1 Tahun 2013 yaitu SKP (sasaran kinerja pegawai) yang meliputi kualitas, kuantitas, waktu, biaya dan PK (perilaku kerja) meliputi orientasi pelayanan, integritas, komitmen, disiplin, kerjasama dan kepemimpinan. Berikut disajikan fenomena dimensi kinerja pegawai pada BKD Kota Pematangsiantar sebagai berikut:

\section{Tabel 1}

Fenomena Kinerja Pegawai

Pada Badan Kepegawaian Daerah (BKD)

\begin{tabular}{|l|c|c|c|c|c|c|}
\multicolumn{7}{|c|}{ Kota Pematangsiantar } \\
\begin{tabular}{|l} 
Aspek \\
$\begin{array}{c}\text { Kinerja } \\
\text { Pegaw } \\
\text { ai }\end{array}$
\end{tabular} & SB & B & CB & TB & $\begin{array}{c}\text { ST } \\
\text { B }\end{array}$ & $\begin{array}{c}\text { Jumla } \\
\text { h }\end{array}$ \\
\hline $\begin{array}{l}\text { Sasara } \\
\text { n }\end{array}$ & & & & & & \\
$\begin{array}{l}\text { Kinerja } \\
\text { Pegaw } \\
\text { ai } \\
\text { (SKP) }\end{array}$ & 30 & 60 & 20 & $0 \%$ & $0 \%$ & $100 \%$ \\
\hline $\begin{array}{l}\text { Perilak } \\
\text { u Kerja } \\
\text { (PK) }\end{array}$ & 20 & 50 & 10 & 10 & $1 \%$ & $100 \%$ \\
\hline $\begin{array}{l}\text { Rata- } \\
\text { rata }\end{array}$ & $\begin{array}{c}\mathbf{2 5} \\
\mathbf{9}\end{array}$ & $\begin{array}{c}\mathbf{5 5} \\
\mathbf{9}\end{array}$ & $\mathbf{1 5}$ & $\mathbf{5 \%}$ & $\begin{array}{c}\mathbf{0} \\
\mathbf{\%}\end{array}$ & $\mathbf{1 0 0 \%}$ \\
\hline
\end{tabular}

Sumber: hasil wawancara dengan Sekretaris BKD (Agustus, 2017)

Dari uraian diatas dapat diketahui kinerja pegawai BKD Kota Pematangsiantar belum optimal. Hal ini dapat terlihat pada dimensi sasaran kerja pegawai yaitu pada aspek kualitas kerja dimana hasil kerja pegawai masih banyak mendapat keluhan dari beberapa pegawai karena kesalahan SK Kenaikan Pangkat, SK Berkala dan hasil kerja yang kurang rapi. Pada dimensi perilaku kerja yaitu pada aspek disiplin karena masih adanya pegawai yang sering tidak masuk kerja dan tidak mengikuti apel pagi dan sore sehingga mendapatkan teguran secara lisan dan tulisan. Pada aspek komitmen masih ada beberapa pegawai yang masuk kerja namun tidak melakukan tugas pokoknya dan kurang memiliki tanggungjawab pada tugasnya

Salah satu faktor yang diindikasikan mempengaruhi kinerja adalah peran seorang pemimpin yang mampu melaksanakan tugasnya dan memelihara hubungan yang baik dengan bawahannya. Seorang pemimpin harus mampu mengarahkan bawahannya dan dapat menjadi contoh peran yang baik untuk dapat meningkatkan kemampuan kinerja bawahannya.

Peran kepemimpinan dalam suatu organisasi atau perusahaan dibutuhkan untuk memajukan organisasi. Pimpinan pada BKD Kota Pematangsiantar disebut sebagai Kepala Badan. Dimensi peran kepemimpinan pada BKD Kota Pematangsiantar dapat dilihat dari peran interpersonal (antar pribadi) dalam hal ini pimpinan sudah berinteraksi dengan baik dalam memberikan motivasi dan arahan kepada bawahannya. Kemudian peran informasional (pemberi informasi), peran pimpinan masih kurang optimal karena Kepala BKD Kota Pematangsiantar masih mempelajari hal-hal yang berkaitan dengan tupoksi BKD sebagai Kepala BKD yang baru. Sebagai pimpinan yang baru Kepala BKD memberikan informasi yang baik kepada pegawainya dan melakukan penyampaian informasi ke luar lingkungan Organisasi. Selanjutnya sebagai peran pengambil keputusan pimpinan melakukan tanggungjawabnya dengan baik, dan jika dibutuhkan dalam mengambil keputusan di saat situasi kritis maupun di situasi tenang.

Faktor lain yang mempengaruhi kinerja adalah kerjasama tim. Kerjasama tim (teamwork) merupakan sekelompok orang-orang yang bekerja bersama untuk mencapai tujuan yang sama dan tujuan tersebut akan lebih mudah diperoleh dengan melakukan kerjasama tim daripada dilakukan sendiri.

Secara keseluruhan dimensi kerjasama tim pada BKD Kota Pematangsiantar berjalan belum Optimal. Dilihat dari dimensi lingkungan, pada BKD Kota Pematangsiantar kurang tercipta lingkungan yang nyaman karena kantor BKD masih kurang luas dalam melakukan aktivitas pekerjaan dan pelayanan kepegawaian sehingga menimbulkan ketidaknyamanan. Kemudian dimensi peran, para pegawai BKD Kota Pematangsiantar sebagian sudah baik namun beberapa pegawai kurang mengetahui dan kurang perduli pada fungsi jabatan dan tugasnya.

Untuk dimensi masalah tim, pegawai BKD

Kota Pematangsiantar masih tidak peka terhadap semua aspek lingkungan, seperti banyaknya pegawai yang tidak perduli terhadap pertumbuhan kerjasama tim sehingga bekerja bersama masih perlu ditingkatkan dalam hal ini peran kepemimpinan sangat dibutuhkan. 
BKD Kota Pematangsiantar menyadari bahwa untuk menciptakan kinerja yang baik harus dilakukan pengoptimalan peran pemimpin dan kerjasama tim. Berdasarkan hal tersebut diatas, penulis tertarik untuk mengetahui lebih lanjut tentang Instansi tersebut, sehingga dalam hal ini penulis tertarik untuk meneliti dengan judul: Pengaruh Peran Kepemimpinan dan Kerjasama Tim terhadap Kinerja Pegawai Pada Badan Kepegawaian Daerah Kota Pematangsiantar.

\section{Rumusan Masalah}

a. Bagaimana gambaran peran kepemimpinan, kerjasama tim dan kinerja pegawai di Badan Kepegawaian Daerah Kota Pematangsiantar.

b. Bagaimana pengaruh peran kepemimpinan dan kerjasama tim terhadap kinerja pegawai di Badan Kepegawaian Daerah Kota Pematangsiantar baik secara simultan maupun parsial.

\section{Tujuan Penelitian}

a. Untuk mengetahui gambaran peran kepemimpinan, kerjasama tim dan kinerja pegawai di Badan Kepegawaaian Daerah Kota Pematangsiantar.

b. Untuk mengetahui pengaruh peran kepemimpinan dan kerjasama tim terhadap kinerja pegawai di Badan Kepegawaian Daerah Kota Pematangsiantar baik secara simultan maupun parsial.

\section{Metode Penelitian}

Lokasi atau tempat penelitian ini dilakukan di BKD Kota Pematangsiantar Jl. Merdeka No. 20 A Pematangsiantar. Pada penelitian ini yang menjadi populasi adalah Pegawai BKD Kota Pematangsiantar sebanyak 43 orang. Seluruh pegawai yang berjumlah 43 orang akan menjadi sampel dan Populasi sebagai responden untuk menjawab kuesioner yang penulis sebarkan, mengingat jumlahnya kurang dari 100 (seratus) orang dan ketersediaan waktu penulis serta untuk keakuratan hasil penelitian.

Adapun Desain penelitian yang digunakan dalam penulisan skripsi ini adalah Penelitian Kepustakaan (Library Research) dan Penelitian Lapangan (Field Research). Teknik pengumpulan data yang dilakukan penulis dalam penelitian ini adalah berupa Kuesioner, Wawancara, Dokumentasi dan Observasi. Adapun jenis data yang digunakan dalam penelitian ini adalah jenis data kualitatif dan data kuantitatif. Hasil data yang diperoleh dari lapangan akan dianalisis secara deskriptif baik bersifat kualitatif dan kuantitatif.

\section{B. LANDASAN TEORI}

1.Manajemen Sumber Daya Manusia

Menurut Mathis dan John (2006:3), manajemen sumber daya manusia adalah rancangan sistem-sistem formal dalam sebuah organisasi untuk memastikan penggunaan bakat manusia secara efektif dan efisien guna mencapai tujuan-tujuan organisasional. Sedangkan menurut Mondy (2008:4), manajemen sumber daya manusia adalah pemanfaatan sejumlah individu untuk mencapai tujuan-tujuan organisasi. Menurut Sutrisno (2009:4), manajemen sumber daya manusia adalah sumber dari kekuatan yang berasal dari manusia-manusia yang dapat didayagunakan oleh organisasi. Berdasarkan beberapa pendapat ahli di atas, penulis menyimpulkan menajemen sumber daya manusia adalah ilmu dan seni mendayagunakan manusia atau proses memperoleh, memajukan, mengembangkan, dan memelihara tenaga kerja agar tujuan organisasi dapat tercapai secara efektif dan efesien.

Fungsi manajemen sumber daya manusia menurut Mondy (2008:4), pada dasarnya ada lima jenis yaitu :

a. Penyediaan staf, merupakan proses yang menjamin suatu organisasi untuk selalu memiliki jumlah karyawan yang tepat dengan keahliankeahlian yang memadai dalam pekerjaanpekerjaan tepat pada waktunya untuk mencapai tujuan organisasi.

b. Pengembangan sumber daya manusia. Fungsi manajemen sumber daya manusia utama yang tidak hanya terdiri atas pelatihan dan pengembangan namun juga aktivitas-aktivitas perencanaan dan pengembangan karier individu, organisasi, serta manajemen dan penilaian kinerja.

c. Kompensasi. Suatu sistem kompensasi yang terencana matang memberi para karyawan imbalan-imbalan yang layak dan andil atas kontribusi mereka dalam mencapai tujuan-tujuan organisasi.

d. Kesehatan dan keselamatan. Keselamatan adalah perlindungan bagi para karyawan yang disebabkan kecelakaan-kecelakaan yang terkait dengan pekerjaan. Kesehatan adalah bebasnya para karyawan dari sakit fisik atau emosi.

e. Hubungan kekaryawanan dan perburuhan. Afiliasi yang dilakukan karyawan dengan pihak perusahaan haruslah dijaga dengan baik, agar karyawan memiliki motivasi untuk mencapai tujuan perusahaan yang telah ditetapkan.

\section{Peran Kepemimpinan}

Menurut Kreitner dan Angelo (2014:201), kepemimpinan adalah sebuah proses dimana seorang individu mempengaruhi yang lain untuk mencapai sasaran yang sama. Menurut Kartono (2006:57), menyebutkan bahwa kepemimpinan adalah kegiatan mempengaruhi dan mengarahkan tingkah laku bawahan atau orang lain untuk mencapai tujuan organisasi atau kelompok. Sedangkan menurut Samsudin (2010:287), kepemimpinan adalah kemampuan meyakinkan dan menggerakkan orang lain agar mau bekerja sama di bawah kepemimpinannya sebagai suatu tim untuk mencapai suatu tujuan tertentu. Sedangkan menurut Dan Menurut Sutrisno (2009:218), kepemimpinan sebagai proses mengarahkan dan mempengaruhi aktivitas yang berkaitan dengan tugas dari para anggota kelompok 
Dari uraian di atas, penulis mengambil kesimpulan bahwa kepemimpinan adalah suatu proses kemampuan atau keahlian seseorang yang dapat mempengaruhi orang lain atau sekelompok orang untuk mencapai tujuan yang diharapkan oleh organisasi atau perusahaan.

\section{Kerjasama Tim}

Menurut Daft (2007:171), tim adalah sebuah unit yang terdiri dari 2 orang atau lebih yang berinteraksi dan mengkoordinasikan pekerjaan mereka untuk menyelesaikan sebuah tugas yang spesifik. Menurut Robbins dan Timothy (2008:406), tim kerja adalah kelompok yang usaha-usaha individualnya menghasilkan kinerja lebih tinggi daripada jumlah masukan individual. Sedangkan Menurut Kreitner dan Angelo (2014:45), kerjasama adalah orang-orang yang bekerjasama saat usaha mereka secara sistematis digabungkan untuk mencapai tujuan bersama.

Berdasarkan pendapat para ahli diatas, penulis mengambil kesimpulan bahwa Kerjasama tim (teamwork) adalah suatu kelompok yang terdiri dari dua orang atau lebih yang bekerja bersama untuk mencapai tujuan yang sama dan tujuan tersebut akan lebih mudah dilaksanakan dengan melakukan kerjasama tim daripada dilakukan sendiri.

\section{Kinerja}

Menurut Sutrisno (2009:151), kinerja adalah prestasi kerja sebagai hasil kerja yang telah dicapai seseorang dari tingkah laku kerjanya dalam melaksanakan aktivitas kerja. Menurut Mangkunegara (2013:67), istilah kinerja berasal dari kata job performance atau actual performance (prestasi kerja atau prestasi sesungguhnya yang dicapai oleh seseorang). Pengertian kinerja (prestasi kerja) adalah ukuran hasil kerja secara kualitas dan kuantitas yang dicapai oleh seseorang pegawai dalam melaksanakan tugasnya sesuai dengan tanggungjawab yang diberikan kepadanya. Mathis dan John (2006:378), kinerja (performance) pada dasarnya adalah apa yang dilakukan atau tidak dilakukan oleh karyawan. Kinerja karyawan yang umum untuk kebanyakan pekerjaan meliputi elemen seperti: kuantitas dan kualitas dari hasil, kehadiran dan kemampuan bekerja sama.

Berdasarkan uraian di atas, penulis menyimpulkan bahwa kinerja adalah hasil kerja pegawai berdasarkan pengukuran prestasi kerja yang telah dicapai sesuai dengan standar atau kriteria yang ditetapkan oleh perusahaan.

Dimensi kinerja adalah Sasaran Kinerja Pegawai (SKP) dan Perilaku Kerja (PK). Sasaran kinerja meliputi unsur sebagai berikut:

a) Kuantitas kerja merupakan ukuran jumlah atau banyaknya hasil kerja yang dicapai oleh seorang pegawai.

b) Kualitas kerja merupakan ukuran mutu setiap hasil kerja yang dicapai oleh seorang pegawai.

c) Waktu merupakan ukuran lamanya proses setiap hasil kerja yang dicapai seorang pegawai.

\section{Pengaruh Peran Kepemimpinan dan Kerjasama Tim Terhadap Kinerja Pegawai}

Keberhasilan suatu organisasi bergantung kepada peran seorang pemimpin dan efektifitas tim kerja, seorang pemimpin diharapkan dapat berperan sebagai figure yang menggerakkan bawahannya dan penuh inisiatif serta cerdas dalam pengambilan keputusan. Peran kepemimpinan merupakan suatu hal yang sangat mempengaruhi tingkat kinerja seorang pegawai. Menurut Sutrisno (2009:218), kepemimpinan sebagai proses mengarahkan dan mempengaruhi aktivitas yang berkaitan dengan tugas dari para anggota kelompok. Kerjasama tim dibentuk bukan hanya untuk menyelesaikan tugas perusahaan, tetapi juga diharapkan dapat memotivasi keseluruhan pegawai yang berada dalam lingkup perusahaan tersebut.

Menurut Robbins dan Timothy (2008:406), kerjasama tim adalah kelompok yang usaha-usaha individualnya menghasilkan kinerja lebih tinggi daripada jumlah masukan individual. Apabila peran kepemimpinan dan kerja sama tim yang diciptakan sesuai dengan harapan pegawai, maka pegawai akan lebih terpuaskan dalam pekerjaannya sehingga output yang dihasilkan pegawai juga akan baik dan tujuan perusahaan dapat tercapai.

\section{PEMbahasan}

\section{Analisis}

\section{a. Deskriptif Kualitatif}

Analisis deskriptif kualitatif dimaksudkan untuk mendapatkan gambaran atau deskripsi mengenai tanggapan dari pegawai mengenai Pengaruh Peran Kepemimpinan dan Kerjasama Tim terhadap Kinerja Pegawai pada BKD Kota Pematangsiantar. Sesudah pegujian data maka langkah selanjutnya penelitian melakukan pengkajian analisis kualitatif sebagai gambaran fenomenal dari variabel penelitian pada saat sekarang ini. Adapun penetapan kriteria nilai ratarata jawaban dari responden tersebut dimasukan kedalam kelas-kelas interval dimana penentuan interval nya memakai rumus sebagai berikut:

Interval Kelas $=$ Nilai Tertinggi - Nilai Terendah ......(Sugiyono, 2010:43)

$$
\begin{aligned}
& =\frac{5-1}{5} \\
& =\frac{4}{5} \\
& =0,8
\end{aligned}
$$

Kriteria:

a. Nilai Tertinggi adalah $=5$

b. Nilai Terendah adalah $=1$

c. Jumlah Kelas adalah $=5$

Dari rumus diatas dapat diperoleh interval kelas 0,8 sehingga berlaku ketentuan kategori dengan hasil sebagai berikut:

Tabel 2 
Nilai Interval dan Kategori Jawaban Responden

\begin{tabular}{|c|c|c|c|}
\hline \multirow{2}{*}{$\begin{array}{c}\text { Nilai } \\
\text { Interval }\end{array}$} & \multicolumn{3}{|c|}{ Kategori } \\
\cline { 2 - 4 } & $\begin{array}{c}\text { Peran } \\
\text { Kepemimpina } \\
\mathbf{n}\end{array}$ & $\begin{array}{c}\text { Kerjasama } \\
\text { Tim }\end{array}$ & $\begin{array}{c}\text { Kinerja } \\
\text { Pegawai }\end{array}$ \\
\hline $\begin{array}{c}1,00- \\
1,80\end{array}$ & $\begin{array}{c}\text { Sangat Tidak } \\
\text { Baik }\end{array}$ & $\begin{array}{c}\text { Sangat Tidak } \\
\text { Baik }\end{array}$ & $\begin{array}{c}\text { Sangat } \\
\text { Tidak Baik }\end{array}$ \\
\hline $\begin{array}{c}1,81- \\
2,60\end{array}$ & Tidak Baik & Tidak Baik & Tidak Baik \\
\hline $\begin{array}{c}2,61- \\
3,40\end{array}$ & Cukup Baik & Cukup Baik & Cukup Baik \\
\hline $\begin{array}{c}3,41- \\
4,20\end{array}$ & Baik & Baik & Baik \\
\hline $\begin{array}{c}4,21- \\
5.00\end{array}$ & Sangat Baik & Sangat Baik & Sangat Baik \\
\hline
\end{tabular}

Sumber: hasil pengolahan data (2017)

\section{Gambaran Peran Kepemimpinan pada Badan} Kepegawaian Daerah Kota Pematangsiantar.

Peran kepemimpinan kepala BKD Kota Pematangsiantar adalah proses mempengaruhi yang dilakukan seorang kepala BKD Kota Pematangsiantar dengan menunjukkan rasa persahabatan, dekat dan perduli terhadap para bawahan. Salah satu dimensi dari peran kepemimpinan BKD Kota Pematangsiantar adalah peranan interpersonal. Dimana pada indikator figur kepala BKD Kota Pematangsiantar memberikan contoh yang baik kepada para pegawainya dan memiliki sikap tegas, berwibawa dan mampu memberikan motivasi pada para bawahannya.

Dimensi peranan informasi yaitu menempatkan pimpinan pada suatu titik strategi untuk mengumpulkan dan menyebarkan informasi, agar kepala BKD Kota Pematangsiantar mampu mengembangkan cara kerja dan pelayanan yang baik dari para pegawai dan mempunyai pemahaman yang komplit tentang lingkungan BKD Kota Pematangsiantar, mengirimkan kembali informasi yang telah relevan ke para bawahannya. Kepala BKD Kota Pematangsiantar melakukan diskusi untuk lebih memahami tentang kepegawaian agar informasi yang disampaikan keluar organisasi benarbenar relevan.

Pada dimensi peran pengambil informasi dengan sikap kewirausahan yang kuat akan berani mengambil keputusan yang tepat dan melakukan perubahan-perubahan yang inovatif. Kepala BKD Kota Pematangsiantar menciptakan perubahan dan menangani masalah yang dihadapi organisasi. Dengan meningkatkan disiplin para pegawai dengan mewajibkan para pegawai hadir untuk mengikuti apel pagi pukul 07.45 WIB dan sore pukul 15.45 WIB setiap harinya. Agar para pegawai BKD Kota Pematangsiantar menjadi contoh bagi para pegawai di luar organisasi BKD Kota Pematangsiantar.

Dimensi peran interpersonal pada indikator figur berada pada rata-rata 4,19 dengan kriteria jawaban baik, hal ini karena pemimpin di dalam melaksanakan tugasnya dalam mewakili organisasi yang dipimpinnya berusaha memberikan contoh yang baik bagi pegawai. Untuk indikator peran Kepala BKD Kota Pematangsiantar sebagai pemimpin berada pada rata-rata 3,91, dengan kriteria jawaban baik. Hal ini disebabkan Kepala BKD Kota Pematangsiantar memiliki sikap pemimpin yang berwibawa dan tegas terhadap setiap pegawai.

Pada indikator peran Kepala BKD Kota Pematangsiantar sebagai penghubung dengan ratarata 4,19 dengan kriteria baik. Hal ini disebabkan kepala BKD Kota Pematangsiantar selalu berusaha untuk berhubungan secara interpesonal kepada seluruh pegawai. Kepala BKD Kota Pematangsiantar seringkali sibuk dengan urusan diluar organisasi seperti pergi untuk koordinasi dan konsultasi mengenai kepegawaian ke BKN Regional IV Medan, BKD Medan, BKN RI di Jakarta maupun ke organisasi lain yang berhubungan dengan kepegawaian dan terkadang melaksanakan tugas keluar daerah atas perintah Walikota Pematangsiantar dan Sekretaris DaerahKota Pematangsiantar.

Pada dimensi peranan informasi dengan indikator keaktifan kepala BKD Kota Pematangsiantar dalam mengembangkan organisasi melalui pengawasan terhadap para pegawai dengan rata-rata 4,19 dengan kriteria jawaban baik. Hal ini disebabkan kepala BKD Kota Pematangsiantar memberikan perhatian melalui kepala bidang untuk menanyakan sampai dimana pekerjaan yang telah dilaksanakan selama ini. Pada indikator penyampai informasi kepada para pegawai kepala BKD Kota Pematangsiantar dengan rata-rata 3,95 dengan kriteria baik. Hal ini karena kepala BKD Kota Pematangsiantar mengadakan rapat internal bila ada hal-hal penting yang harus di informasikan terlebih mengenai perubahan peraturan pada kebijakan kepegawaian. Pada indikator sebagai juru bicara dalam menyampaikan informasi kepala BKD Kota Pematangsiantar berada pada rata-rata 3,93 dengan kriteria baik. Dalam hal ini kepala BKD Kota Pematangsiantar mampu menjadi juru bicara menyampaikan informasi ke Organisasi Perangkat Daerah (OPD) lainnya.

Pada dimensi peranan pengambil keputusan pada indikator tindakan kepala BKD Kota Pematangsiantar sebagai wirausaha dengan rata-rata 4,21 dengan kriteria jawaban sangat baik. Dalam hal ini kepala BKD Kota Pematangsiantar sudah menciptakan perubahan dan menangani masalah yang dihadapi pada organisasi. Hal ini terlihat dari semakin membaiknya pembagian tugas pada BKD Kota Pematangsiantar dan pekerjaan dilaksanakan sesuai dengan tugas pokok dan fungsi pada bidang masing-masing. Pada indikator kepala BKD Kota Pematangsiantar sebagai penengah keributan dengan rata-rata 3,93 dengan kriteria jawaban baik. Hal ini disebabkan kepala BKD Kota Pematangsiantar menjalankan perannya dengan baik sebagai penengah dalam keributan, terlihat pada saat pagu (budget) anggaran BKD Kota Pematangsiantar telah ditetapkan oleh Tim Anggaran, dan dalam pembagian tiap bidang mempertahankan kegiatan masing-masing akan tetapi pagu (budget) yang diberikan masih minim, kepala BKD Kota Pematangsiantar menjadi penengah dengan \begin{tabular}{llr}
\hline \hline Jurnal SULTANIST & ISSN : 2338-4328 Vol. 6, No. 1, JUNI 2018 & 16
\end{tabular} 
mengambil keputusan bahwa kepala sub bidang program, evaluasi dan keuangan yang menentukan apa saja yang menjadi kegiatan prioritas pada BKD Kota Pematangsiantar.

Pada indikator peran kepala BKD Kota Pematangsiantar dalam pengalokasian SDM dengan rata-rata 3,98 dengan kriteria jawaban baik. Hal ini dikarenakan masih ada beberapa pegawai yang masih belum ditempatkan pada bidang sesuai dengan latar belakang pendidikannya. Pada indikator kepala BKD Kota Pematangsiantar sebagai negosiator dengan rata-rata 3,72 dengan kriteria jawaban baik. Hal ini karena kepala BKD Kota Pematangsiantar melakukan negosiator dengan baik kepada pegawai didalam organisasi maupun diluar organisasi. Dan pada indikator penentu kebijakankepala BKD Kota Pematangsiantar dengan rata-rata 4,02 dengan kriteria jawaban baik. Hal ini disebabkan kepala BKD Kota Pematangsiantar mampu menentukan kebijakan bagi perkembangan organisasi.

Secara keseluruhan dapat dilihat bahwa ratarata peran kepemimpinan pada BKD Kota Pematangsiantar pada dimensi peranan interpersonal, pada indikator peranan peranan informasi dan peranan pengambil keputusan berada pada nilai rata-rata 4,02 dengan kriteria jawaban baik. Nilai rata-rata peran kepemimpinan tertinggi ada pada dimensi peran pengambil keputusan dengan indikator pengawas nilai rata-rata 4,21 yang berkriteria jawaban sangat baik. Nilai rata-rata peran kepemimpinan terendah berada pada dimensi peran pengambil keputusan dengan indikator negosiator dengan nilai rata-rata 3,72 yang berkriteria jawaban baik.

\section{Gambaran Kerjasama Tim pada Badan Kepegawaian Daerah (BKD) Kota Pematangsiantar.}

Kerjasama tim pada BKD Kota Pematangsiantar adalah interaksi dan saling koordinasi antara sesama pegawai maupun koordinasi dengan pimpinan untuk menyelesaikan tugas-tugas kepegawaian. Tanpa kerjasama yang baik pada BKD Kota Pematangsiantar tidak akan dapat menyelesaiakan pekerjaan dengan optimal dan tidak akan memunculkan ide-ide cemerlang dalam menyelesaikan pekerjaan. Pada BKD Kota Pematangsiantar salah satu dimensi kerjasama tim adalah dimensi lingkungan. Dimana pada indikator kecocokan pegawai BKD Kota Pematangsiantar berusaha menyesuaikan diri untuk menyelesaikan suatu pekerjaan untuk mendapatkan hasil yang optimal.

Dimensi peran yaitu para pegawai BKD Kota Pematangsiantar mengetahu peran masing-masing dalam menyelesaikan tugas pokok dan fungsi masing-masing. Pada indikator tugas para pegawai melaksanakan tugasnya dengan cukup baik dengan menyelesaikan pekerjaan tepat waktu.

Dimensi tujuan yaitu menempatkan setiap kepala bidang pada BKD Kota Pematangsiantar untuk menjaga agar para pegawai tetap fokus pada tugas masing-masing. Dimana pada indikator misi BKD Kota Pematangsiantar memiliki tujuan untuk mengoptimalkan seluruh sumber daya kepegawaian melalui peningkatan dan pengembangan kualitas SDM.

Pada dimensi masalah tim pegawai BKD Kota Pematangsiantar menyelesaikan bersama melalui rapat pegawai untuk mencari jalan keluar dari masalah yang menghambat kelancaran pekerjaan. Melalui rapat para pegawai saling koordinasi dan konsultasi untuk melancarkan pekerjaan, selain itu dapat mempererat kerjasama dengan saling terbuka. dimensi lingkungan pada indikator suportif berada pada rata-rata 2,74 dengan kriteria jawaban cukup baik, dikarenakan para pegawai cukup mampu bekerjasama dalam mencari pemecahan masalah yang terjadi pada tim kerja. Pada indikator kerjasama berada pada rata-rata 2,74 dengan kriteria jawaban cukup baik, hal ini karena kerjasama yang terjalin antara sesama pegawai di BKD Kota Pematangsiantar terjalin dengan cukup baik. Untuk indikator saling percaya berada pada rata-rata 2,74 dengan kriteria jawaban cukup baik karena rasa saling percaya yang cukup baik antara pegawai dengan rekan kerja yang lain. Dan pada indikator kecocokan berada pada rata-rata 4,26 dengan kriteria jawaban sangat baik, hal ini disebabkan adanya kecocokan yanga sangat baik antar sesama pegawai untuk bekerjasama mencapai tujuan dan target BKD Kota Pematangsiantar.

Kemudian untuk dimensi peran pada indikator jabatan berada pada rata-rata 3,67 dengan kriteria jawaban sangat baik, karena pada BKD Kota Pematangsiantar khususnya pada pembagian jabatan terjalin dengan sangat baik. Demikian juga pada indikator tugas berada pada rata-rata 2,77 dengan kriteria cukup baik, karena pada BKD Kota Pematangsiantar khususnya pada pembagian tugas masih cukup baik

Dan pada indikator wewenang berada pada rata-rata 3,67 dengan kriteria jawaban baik, hal ini karena wewenang yang diberikan oleh BKD Kota Pematangsiantar kepada pegawai berjalan dengan baik. Begitu juga pada indikator hak, berada pada rata-rata 4,19 dengan kriteria jawaban baik, karena hak yang diberikan oleh BKD Kota Pematangsiantar diterima oleh pegawai dengan baik. Lalu pada indikator kewajiban, berada pada rata-rata 4,19 dengan kriteria jawaban baik, karena kewajiban yang dilakukan oleh pegawai BKD Kota Pematangsiantar dijalankan oleh pegawai dengan baik.

Selanjutnya pada dimensi tujuan di indikator pencapaian berada pada rata-rata 3,72 dengan kriteria jawaban baik, karena kerjasama tim yang dilakukan pegawai untuk mencapai target yang diberikan oleh BKD Kota Pematangsiantar berjalan dengan baik. Untuk indikator fungsi perencanaan berada pada rata-rata 2,77 dengan kriteria jawaban cukup baik, hal ini dikarenakan sebelum melakukan pekerjaan para pegawai membuat perencanaan untuk mengkonsep rancangan pekerjaan yang akan dilakukan akan tetapi masih belum optimal. Kemudian pada indikator misi berada pada rata-rata 
4,16 dengan kriteria jawaban baik, karena misi yang dilakukan untuk mewujudkan visi pada BKD Kota Pematangsiantar dijalankan dengan baik.

Selanjutnya pada dimensi masalah tim untuk indikator hubungan kerja yang saling mendukung berada pada rata-rata 4,26 dengan kriteria jawaban sangat baik, hal ini dikarenakan di BKD Kota Pematangsiantar terjalin hubungan kerja yang sangat baik, dari atasan kepada bawahan begitu juga sebaliknya. Untuk indikator komunikasi berada pada rata-rata 4,26 dengan kriteria jawaban sangat baik, karena komunikasi yang terjalin antara pimpinan dan bawahan selalu terjalin dengan baik. Begitu juga dengan indikator pemecahan masalah berada pada rata-rata 4,28 dengan kriteria jawaban sangat baik, hal ini dikarenakan jika ada masalah yang timbul dilingkungan BKD Kota Pematangsiantar, para pegawai sama-sama mencari jalan keluar untuk memecahkan masalah yang ada.

Secara keseluruhan dapat dilihat bahwa rata-rata kerjasama tim di BKD Kota Pematangsiantar pada dimensi lingkungan, peran, tujuan dan masalah tim berada pada nilai rata-rata 3,63 dengan kriteria jawaban baik. Nilai rata-rata kerjasama tim tertinggi ada pada dimensi masalah tim dengan indikator pemecahan masalah yaitu 4,28 dengan kriteria jawaban baik. Dan nilai rata-rata kerjasama tim terendah berada pada dimensi lingkungan dengan indikator supportif, kerjasama dan saling percaya yaitu 2,74 dengan kriteria jawaban cukup baik.

\section{Gambaran Kinerja Pegawai pada Badan Kepegawaian Daerah (BKD) Kota Pematangsiantar}

Kinerja pegawai BKD Kota Pematangsiantar merupakan prestasi kerja yang dicapai oleh pegawai dan sudah diukur berdasarkan stándar kriteria yang ditetapkan oleh pemerintah yang sesuai dengan Peraturan Pemerintah (PP) nomor 46 tahun 2011 dan Peraturan Kepala Badan Kepegawaian Negara (Perka BKN) nomor 3 tahun 2013. Salah satu dimensi kinerja pegawai pada BKD Kota Pematangsiantar yaitu Sasaran Kerja Pegawai (SKP). Dimana pada indikator kuantitas, pegawai BKD Kota Pematangsiantar bertanggungjawab pada pekerjaannya dan berusaha mencapai target kerja melalui koordinasi dan konsultasi dengan BKD Propsu Medan dan Kantor Regional VI BKN Propsu Medan untuk memberikan kepuasan pelayanan pada para pegawai Pemerintah Kota Pematangsiantar. Dimensi Perilaku Kerja (PK) memberikan pelayanan yang terbaik kepada pegawai pemerintah Kota Pematangsiantar salah satunya dengan menyebarkan surat edaran kenaikan pangkat PNS setiap periode April dan Oktober agar pegawai yang akan naik pangkat dapat mengusulkan kenaikan pangkatnya tepat waktu. Selain itu pegawai BKD Kota Pematangsiantar memberikan pelayanan dengan memeriksa usulan kenaikan pangkat pegawai sesuai dengan syarat-syarat kenaikan pangkat dan membantu mencari solusi apabila ada kendala dalam memenuhi syarat kenaikan pangkat tersebut.
Dimensi sasaran kinerja pegawai indikator pertanggungjawaban hasil berada pada rata-rata 4,37 dengan kriteria jawaban sangat baik, karena pegawai melaksanakan pekerjaannya dengan baik. Pada indikator pencapaian target kerja berada pada ratarata 4,28 dengan kriteria jawaban sangat baik, hal ini karena pegawai mampu mencapai target kerja yang ditentukan oleh organisasi. Untuk indikator menangani pekerjaan diluar tugas utama berada pada rata-rata 4,19 dengan kriteria jawaban baik, karena pegawai melaksanakan pekerjaan lain yang ditugaskan oleh pimpinan dengan baik.

Selanjutnya pada indikator hasil kerja pegawai berada pada rata-rata 4,19 dengan kriteria jawaban baik, hal ini disebabkan pegawai mampu menyelesaikan pekerjaannya dengan baik. Pada indikator ketelitian dalam bekerja berada pada ratarata 4,19 dengan kriteria jawaban baik karena pegawai teliti dalam pekerjaannya. Kemudian indikator kerapian dalam bekerja berada pada ratarata 3,70 dengan kriteria jawaban baik karena pegawai bekerja dengan baik dan berusaha mengerjakan pekerjaannya dengan optimal.

Pada indikator efisiensi waktu dalam bekerja berada pada rata-rata 4,00 dengan kriteria jawaban baik, hal ini disebabkan pegawai dalam menyelesaikan suatu pekerjaan sesuai waktu yang telah ditentukan. Pada indikator penyelesaian pekerjaan tepat waktu berada pada rata-rata 4,16 dengan kriteria jawaban baik, karena pegawai melakukan pekerjaannya dengan sesuai waktu yang ditentukan. Pada indikator penggunaan waktu yang maksimal berada pada rata-rata 4,19 dengan kriteria jawaban baik, kerena pegawai mempergunakan waktu yang ada untuk penyelesaian pekerjaan semaksimal mungkin agar pekerjaan dapat selesai dengan baik.

Pada indikator jumlah anggaran dalam penyelesaian pekerjaan berada pada rata-rata 4,28 dengan kriteria jawaban sangat baik, hal ini disebabkan karena pegawai BKD Kota Pematangsiantar mengalokasikan dana yang diberikan sesuai dengan program kegiatan yang dilaksanakan oleh setiap bidang. Indikator anggaran tunjangan prestasi kerja pegawai berada pada ratarata 4,19 dengan kriteria jawaban baik, karena pegawai mendapatkan tunjangan tambahan penghasilan pegawai setiap bulannya diluar gaji pokok dan jumlah nominal yang didapat oleh pegawai sesuai dengan hasil pekerjaan masingmasing yang dibuat dalam bentuk laporan hasil bulanan. Selanjutnya pada indikator pengelolaan anggaran berada pada rata-rata 4,19 dengan kriteria jawaban baik, karena pegawai menggunakan anggaran yang ada sesuai dengan pos-pos belanja yang telah ditetapkan.

Untuk dimensi perilaku kerja pada indikator sikap dalam bekerja berada pada rata-rata 4,19 dengan kriteria jawaban baik, karena dalam melakukan pekerjaan, pegawai BKD Kota Pematangsiantar bekerja dengan sopan dan berprilaku baik. Pada indikator kualitas pelayanan berada pada rata-rata 4,19 dengan kriteria jawaban 
baik, karena pegawai memberikan pelayanan yang baik kepada pegawai yang sedang mengurus masalah kepegawaiannya baik, yang bermasalah maupun pengurusan untuk kenaikan pangkat dan lai-lainnya. Untuk indikator ketepatan waktu pelayanan berada pada rata-rata 4,19 dengan kriteria jawaban baik, karena pegawai melayani pegawai yang datang ke BKD Kota Pematangsiantar tepat waktu sesuai dengan waktu jam kerja yang ditetapkan oleh pemerintah.

Pada indikator etika dalam bekerja berada pada rata-rata 3,98 dengan kriteria jawaban baik, karena pegawai BKD Kota Pematangsiantar memiliki etika yang baik dalam bekerja. Pada indikator konsistensi dalam bekerja berada pada ratarata 3,95 dengan kriteria jawaban baik, hal ini terlihat dari hasil pekerjaan pegawai yang tetap dan tidak berbeda dari peraturan kepegawaian. Pada indikator kemampuan berada pada rata-rata 3,74 dengan kriteria jawaban baik, karena pegawai memiliki kemampuan yang baik dalam bekerja.

Selanjutnya pada indikator kemauan dalam menyelesaikan pekerjaan berada pada rata-rata 3,77 dengan kriteria jawaban baik, hal ini disebabkan pegawai BKD Kota Pematangsiantar memiliki kemauan yang baik untuk menyelesaikan pekerjaaanya dengan baik. Pada indikator tanggungjawab dalam menyelesaikan pekerjaan berada pada rata-rata 3,98 dengan kriteria jawaban baik, karena pegawai BKD Kota Pematangsiantar memiliki tanggung jawab dalam menyelesaikan pekerjaanya dengan baik. Untuk indikator loyalitas pada organisasi berada pada rata-rata 3,74 dengan kriteria jawaban baik, karena pegawai pegawai bekerja dengan baik untuk perkembangan organisasi.

Pada indikator tingkat kehadiran berada pada rata-rata 4,00 dengan kriteria jawaban baik, karena pegawai BKD Kota Pematangsiantar selalu hadir tepat waktu dalam bekerja dan pulang pada jam pulang kerja. Untuk indikator kepatuhan dalam menaati peraturan berada pada rata-rata 3,84 dengan kriteria jawaban baik, karena pegawai menaati peraturan yang telah ditetapkan oleh pemerintah. Pada indikator kewajiban dalam melaksanakan tugas berada pada rata-rata 4,00 dengan kriteria jawaban baik, karena pegawai melakukan kewajibannya dalam bekerja dengan baik.

Secara keseluruhan nilai kinerja pegawai pada BKD Kota Pematangsiantar memiliki nilai rata-rata 4,06 dengan kriteria jawaban baik. Pada dimensi sasaran kerja pegawai pada indikator tanggungjawab dalam bekerja yang berada pada nilai rata-rata 4,37 dengan kriteria jawaban sangat baik. Sedangkan nilai jawaban responden terendah berada pada dimensi perilaku kerja dengan indikator loyalitas berada pada nilai rata-rata 3,74 dengan kriteria jawaban baik.

\section{b. Deskriptif Kuantitatif}

\section{1) Regresi Linear Sederhana}

Penelitian ini memiliki tujuan untuk menganalisa pengaruh peran kepemimpinan dan kerjasama tim terhadap kinerja pegawai. Analisa data dalam penelitian ini menggunakan analisa regresi linier berganda. Analisa regresi linier berganda digunakan untuk mengetahui pengaruh variabel bebas $(\mathrm{X})$ dan variabel terikat $(\mathrm{Y})$, yaitu $\mathrm{X}_{1}$ adalah peran kepemimpinan dan $\mathrm{X}_{2}$ adalah kerjasama tim serta $\mathrm{Y}$ adalah kinerja pegawai.: Untuk persamaan regresi berganda yang dipergunakan adalah sebagai berikut:

$$
\hat{\mathrm{Y}}=\mathrm{b}_{0}+\mathrm{b}_{1} \mathrm{X}_{1}+\mathrm{b}_{2} \mathrm{X}_{2}
$$

(Simbolon, 2009:239)

Keterangan :

$\hat{\mathrm{Y}}=$ Variabel Terikat (Kinerja Pegawai)

$\mathrm{b}_{0} \quad=$ Konstanta

$\mathrm{b}_{1}, \mathrm{~b}_{2}=$ Koefisien Arah Regresi

$\mathrm{X}_{1} \quad=$ Variabel $\quad$ Bebas 1 (Peran

Kepemimpinan)

$\mathrm{X}_{2}=$ Variabel Bebas 2 (Kerjasama Tim)

Berdasarkan hasil pengolahan data didapat persamaan regresi linier sederhana yaitu:

$\hat{\mathrm{Y}}=\hat{\mathrm{Y}}=24,495+0,395 \mathrm{X}_{1}+0,991 \mathrm{X}_{2}$, artinya terdapat pengaruh positif antara variabel peran kepemimpinan dan kerjasama tim terhadap kinerja pegawai pada BKD Kota Pematangsiantar..

\section{2) Koefisen Korelasi dan Determinasi}

Untuk menghitung kekuatan hubungan peran kepemimpinan dan kerjasama tim terhadap kinerja pegawai dilakukan perhitungan korelasi berupa derajat atau kedalaman hubungan fungsional yang menjelaskan hubungan antara perubah, dinyatakan dengan koefisien korelasi yang sering disimbolkan dengan $r$.

Nilai $r=0,793$, artinya terdapat hubungan yang kuat dan positif antara peran kepemimpinan dan kerjasama tim dengan kinerja pegawai pada BKD Kota Pematangsiantar.

Dari perhitungan koefisian determinasi diperoleh nilai sebesar 0,628, artinya tinggi rendahnya kinerja pegawai $62,8 \%$ dapat dijelaskan oleh peran kepemimpinan dan kerjasama tim pada BKD Kota Pematangsiantar dan sisanya 37,2\% dapat dijelaskan oleh faktor lain seperti motivasi, kompetensi, kompensasi, pengembangan karir dan prestasi kerja yang tidak dibahas dalam penelitian ini.

\section{3) Uji Hipotesis}

a) Uji Simultan (Uji F)

Uji $\mathrm{F}$ digunakan untuk mengetahui apakah varabel bebas (peran kepemimpinan dan kerjasama tim) berpengaruh terhadap variabel terikat (kinerja pegawai) secara bersama-sama atau simultan. Pengujian ini dilakukan jika $F_{\text {hitung }}>F_{\text {tabel }}$ atau signifikansi $\leq 0,05$ maka $\mathrm{H}_{0}$ ditolak, artinya peran kepemimpinan dan kerjasama tim berpengaruh positif dan signifikan terhadap kinerja pegawai pada BKD Kota Pematangsiantar.

Diperoleh nilai $F_{\text {hitung }}$ sebesar 33,786 $>\mathrm{F}_{\text {tabe }}$ $(0,05 ; 2$ VS 40) dengan $\mathrm{df}=\mathrm{n}-\mathrm{k}-1$ sebesar 3,23 atau dengan taraf signifikansi $0,000<\alpha 0,05$, maka $\mathrm{H}_{0}$ ditolak, artinya peran kepemimpinan dan kerjasama 
tim berpengaruh positif dan signifikan terhadap kinerja pegawai pada BKD Kota Pematangsiantar.

\section{b) Uji Parsial (Uji t)}

Uji t digunakan untuk menguji variabel bebas terhadap variabel terikat secara parsial. Untuk menguji hasil perhitungan regresi dapat dilakukan pengujian hipotesis untuk mengetahui apakah variabel bebas mempunyai pengaruh atau tidak terhadap variabel terikat secara parsial.

Nilai $t_{\text {hitung }}$ pada variabel peran kepemimpinan sebesar $2,572>\mathrm{t}_{\text {tabel }}$ dengan $\mathrm{df}=\mathrm{n}-\mathrm{k}-1$ $(43-2-1=40)$ sebesar 2,021, atau dengan taraf signifikansi $0,014<\alpha 0,05$, maka $\mathrm{H}_{0}$ ditolak, artinya peran kepemimpinan berpengaruh positif dan signifikan terhadap kinerja pegawai pada BKD Kota Pematangsiantar.

Kemudian nilai $t_{\text {hitung }}$ pada variabel kerjasama tim sebesar 6,497 $>\mathrm{t}_{\text {tabel }}$ dengan $\mathrm{df}=\mathrm{n}-\mathrm{k}-1(43-2-1=$ 40) sebesar 2,021, atau dengan taraf signifikan 0,000 $<\alpha 0,05$, maka $\mathrm{H}_{0}$ ditolak, artinya kerjasama tim berpengaruh positif dan signifikan terhadap kinerja pegawai pada BKD Kota Pematangsiantar.

\section{Evaluasi \\ a.Peran Kepemimpinan pada Badan Kepegawaian Daerah Kota Pematangsiantar \\ Berdasarkan ketiga dimensi yang digunakan} dalam penelitian ini, hasil yang diperoleh dapat dijelaskan bahwa peran kepemimpinan yang ada pada BKD Kota Pematangsiantar dapat dikatakan baik, baik dari peranan interpersonal, peranan informasi dan peranan pengambil keputusan. Hal tersebut dibuktikan berdasarkan hasil kuisioner yang diperoleh nilai rata-rata 4,02 dengan kriteria jawaban baik.

Namun masih terdapat indikator yang nilainya masih dibawah nilai rata-rata yang perlu menjadi perhatian BKD Kota Pematangsiantar dan dapat diperbaiki untuk menghasilkan peran kepemimpinan yang lebih optimal. Pada dimensi peran interpersonal dengan indikator pemimpin berada pada nilai rata-rata 3,91 dengan kriteria jawaban baik hal ini dapat diperbaiki dengan cara pemimpin BKD Kota Pematangsiantar mempererat hubungan kekeluargaan dengan para pegawai melalui terlebih dahulu mengenal setiap pegawai baik nama, latar belakang pendidikan dan sangat baik apabila pemimpin juga bisa melihat talenta dan kemampuan para bawahannya.

Pada dimensi peran informasi dengan indikator pemberi informasi berada pada nilai ratarata 3,95 dengan kriteria jawaban baik, hal ini dapat diperbaiki dengan cara pemimpin dalam menyampaikan informasi kepada pegawai sebaiknya menyampaikan informasi dengan mengumpulkan seluruh pegawainya melalui rapat internal. Informasi yang berkaitan dengan pelaksanaan kegiatan yang akan dilaksanakan oleh BKD Kota Pematangsiantar perlu diketahui oleh semua pegawai, sehingga saat pegawai diluar BKD Kota Pematangsiantar mencari informasi tentang kegiatan yang akan dilaksanakan mampu memberi jawaban yang tepat. Selanjutnya indikator juru bicara berada pada nilai rata-rata 3,93 dengan kriteria jawaban baik, hal ini dapat ditingkatkan dengan cara pemimpin mampu menguasai tugas pokok dan fungsi setiap bidang yang ada pada BKD Kota Pematangsiantar sehingga saat memberikan informasi keluar organisasi dapat dipertanggungjawabkan.

Selanjutnya pada dimensi peran pengambil keputusan dengan indikator menghadapi masalah berada pada nilai rata-rata 3,93 dengan kriteria jawaban baik, hal ini dapat ditingkatkan dengan pemimpin lebih menguasai tugas pokok dan fungsi tentang kepegawaian. Pada dindikator penengah keributan berada pada nilai rata-rata 3,98 dengan kriteria jawaban baik, hal ini dapat ditingkatkan dengan pimpinan mengajak pegawai yang berkonflik berbicara secara kekeluargaan dengan tidak berpihak kepada salah satu pihak. Pada indikator pengalokasian sumber daya berada pada nilai ratarata 3,98 dengan kriteria jawaban baik, hal ini dapat ditingkatkan dengan menempatkan pegawai di bidang tugas yang sesuai dengan latar belakang pendidikannya. Pada indikator negosiator berada pada nilai rata-rata 3,72 dengan kriteria jawaban baik, hal ini dapat ditingkatkan dengan menguasai setiap tugas-tugas pokok dan fungsi disetiap bidang yang ada pada BKD Kota Pemangsiantar sehingga waktu memberikan argumen tentang organisasi akan lebih meyakinkan.

Dari uraian diatas dapat disimpulkan bahwa ketiga dimensi peran kepemimpinan secara teoritisnya seharusnya merupakan suatu mata rantai yang saling berinteraksi, saling melengkapi, dan saling mendukung satu sama lainnya di dalam mencapai kinerja yang baik.

\section{b.Kerjasama Tim pada Badan Kepegawaian Daerah Kota Pematangsiantar}

Berdasarkan dimensi yang digunakan dalam penelitian ini, hasil yang diperoleh dapat dijelaskan bahwa kerjasama tim yang ada pada BKD Kota Pematangsiantar dapat dikategorikan baik. Karena dapat dibuktikan berdasarkan hasil kuisioner yang diperoleh dengan rata-rata 3,63 dengan kriteria jawaban baik. Namun ada beberapa indikator yang perlu ditingkatkan karena masih berada di bawah rata-rata nilai indikator keseluruhannya.

Dimensi lingkungan memiliki kriteria jawaban baik, lalu indikator yang paling rendah berada pada indikator supportif, kerjasama dan saling percaya memperoleh nilai rata-rata 2,74 berkriteria jawaban cukup baik. Cara yang dilakukan oleh BKD Kota Pematangsiantar agar lingkungan yang suportif, kerjasama, dan sikap saling percaya antar pegawai selalu terjalin dengan baik di organisasi maka perlu dilakukan komunikasi yang baik oleh pimpinan kepada pegawai, seperti memberi kesempatan kepada pegawai untuk menyampaikan pernyataannya, dan menunjukkan perhatian kepada pegawai, bahwa informasi yang diterima adalah penting sebagai kontribusi bagi kemajuan organisasi. 
Selanjutnya untuk dimensi peran rata-rata memiliki kriteria jawaban baik, lalu pada indikator pembagian tugas yang memperoleh nilai rata-rata 2,77 dengan kriteria jawaban cukup baik. Untuk mengatasi hal tersebut, maka pimpinan harus mempertegas dan menegaskan apa tugas pokok dan fungsi setiap pegawai yang diterapkan pada BKD Kota Pematangsiantar, sesuai dengan Peraturan Walikota nomor 5 tahun 2017, tanggal 17 Januari 2017. Dengan berjalannya pembagian jabatan, pembagian tugas, wewenang, hak dan kewajiban yang baik, maka otomatis akan menghasilkan kinerja yang optimal.

Kemudian pada dimensi tujuan berada pada kriteria jawaban baik, lalu untuk indikator fungsi perencanaan berada pada rata-rata 2,77 dengan kriteria jawaban cukup baik, hal ini dapat diperbaiki dengan cara setiap Kepala Bidang maupun Sub Bidang harus lebih teliti dalam memeriksa hasil kerja pejabat pelaksana administrasi umum dan lebih tegas lagi untuk melaksanakan diskusi dan merancang perencanaan pekerjaan yang akan di lakukan. Secara keseluruhan untuk dimensi tujuan pada BKD Kota Pematangsiantar berjalan dengan baik, namun dalam hal ini pimpinan harus dapat menjaga bawahannya agar tetap berorientasi pada tugas mereka secara menyeluruh, dengan cara meningkatkan komunikasi yang efektif.

Dengan memperhatikan hal-hal kecil, maka perusahaan telah membuat para pegawainya nyaman dan aman dalam melakukan pekerjaannya. Yang dapat meningkatkan produktivitas kerja, kualitas kerja, mentalitas kerja, meningkatkan kemajuan perusahaan dan saling mendukung antar sesama pegawai dalam organisasi.

\section{c.Kinerja Pegawai pada Badan Kepegawaian Daerah Kota Pematangsiantar}

BKD Kota Pematangsiantar mencapai tujuan perusahaan melalui kinerja para pegawainya. Kinerja merupakan hasil dari apa yang telah dikerjakan oleh para pegawai dan kinerja pegawai dapat dilihat dari prestasi kerja seorang pegawai. Kinerja Pegawai dapat diukur dengan dimensi Sasaran Kerja Pegawai yang meliputi kualitas, kuantitas, waktu, biaya dan PK (perilaku kerja) meliputi orientasi pelayanan, integritas, komitmen, disiplin, kerjasama dan kepemimpinan. Kinerja pegawai pada BKD Kota Pematangsiantar dapat dinilai baik, hal ini dibuktikan dengan nilai rata-rata 4,06 dalam penelitian ini.

Namun masih terdapat indikator yang nilainya masih dibawah nilai rata-rata yang perlu menjadi perhatian BKD Kota Pematangsiantar dan dapat diperbaiki untuk menghasilkan kinerja pegawai yang lebih optimal. Pada dimensi sasaran kinerja pegawai indikator kerapian dalam menyelesaikan pekerjaan dengan nilai rata-rata 3,70 dengan kriteria jawaban baik, maka dalam hal ini organisasi perlu meningkatkan kerapian hasil pekerjaan pegawai dengan cara atasan langsung pegawai selalu memeriksa hasil pekerjaan dan lebih menguasai tugas-tugas pokok kepegawaian dibanding bawahannya dan bukan sebaliknya.
Dengan kemampuan pemimpin yang menguasai pekerjaan makan hasil kerja para bawahannya akan lebih optimal.

Pada indikator efisiensi waktu dalam menyelesaikan pekerjaan berada pada nilai rata-rata 4,00 dengan kriteria jawaban baik. Dalam hal ini dapat ditingkatkan dengan cara setiap atasan langsung memperhatikan setiap hasil pekerjaan dari bawahannya, untuk mengerjakan satu tugas yang diberikan butuh waktu berapa lama dalam mengerjakannya, agar pekerjaan yang hanya dapat diselesaikan dalam waktu yang singkat dikerjakan dalam waktu yang lama.

Kemudian dari dimensi perilaku kerja indikator etika dalam bekerja dengan nilai rata-rata 3,98 dengan kriteria jawaban baik. Hal ini dapat ditingkatkan dengan mengadakan pelatihan dalam pelayanan kedaerah lain yang memiliki etika kwalitas pelayanan yang baik. Pada indikator konsistensi dalam bekerja dengan nilai rata-rata 3,95 dengan kriteria jawaban baik, hal ini dapat ditingkatkan dengan pendekatan pimpinan kepada bawahan untuk memberikan nasehat dan bimbingan dalam melakukan pekerjaannya. Kemudian indikator kemampuan dengan nilai rata-rata 3,74 dengan kriteria jawaban baik, hal ini dapat ditingkatkan dengan mengirim pegawai untuk pendidikan dan pelatihan maupun mengikuti bimbingan teknis tentang kepegawaian.

Pada indikator tingkat kemauan dalam bekerja dengan nilai rata-rata 3,77 kriteria jawaban baik. Dalam hal ini untuk meningkatkan kemauan dalam bekerja, atasan langsung perlu lebih tegas pada pegawai yang mengabaikan pekerjaanya, misalnya : pada tambahan penghasilan pegawai untuk laporan pengukuran prestasi kerja bulanan diberikan $0 \%$ pada aspek penilaian pelaksanaan tugas pokok bagi pegawai yang malas bekerja. Pada indikator tanggungjawab menyelesaikan pekerjaan dengan nilai rata-rata 3,98 dengan kriteria jawaban baik. Hal ini dapat ditingkatkan dengan ketegasan pimpinan dalam memberikan teguran pada bawahannya, misalnya : pada tambahan penghasilan pegawai untuk laporan pengukuran prestasi kerja bulanan diberikan $0 \%$ pada aspek penilaian pelaksanaan tugas pokok bagi pegawai yang tidak bertanggungjawab pada tugas pokoknya. Selanjutnya pada indikator loyalitas pada instansi dengan nilai rata-rata 3,74 dengan kriteria jawaban baik, hal ini dapat ditingkatkan dengan pimpinan lebih memperhatikan kesejahteraan pegawai yang ada BKD Kota Pematangsiantar, misalnya : dengan menganggarkan uang lembur bagi pegawai yang bekerja lebih lama dari jam kerja yang ditetapkan.

Pada indikator tingkat kehadiran setiap hari dengan nilai rata-rata 4,00 dengan kriteria jawaban baik. Hal ini dapat ditingkatkan dengan pimpinan lebih tegas dalam memberikan hukuman disiplin bagi pegawai yang tidak hadir tanpa alasan. Misalnya : dengan tidak membayarkan uang lauk pauk pegawai yang tidak hadir dan pada tambahan penghasilan pegawai untuk laporan pengukuran prestasi kerja bulanan diberikan $0 \%$ untuk aspek 
penilaian kehadiran. Pada indikator kepatuhan menaati peraturan dengan nilai rata-rata 3,84 dengan kriteria jawaban baik. Hal ini dapat ditingkatkan dengan memberikan teguran secara lisan maupun tulisan kepada pegawai yang melanggar peraturan. Selanjutnya pada indikator kewajiban melaksanakan tugas dengan nilai rata-rata 4,00 dengan kriteria jawaban baik. Hal ini dapat ditingkatkan dengan atasan langsung memperhatikan setiap bawahannya apakah melakukan pekerjaannya dengan baik dan tidak membebankan pekerjaan satu bidang hanya kepada beberapa pegawai saja akan tetapi pekerjaan wajib dikerjakan bersama oleh setiap pegawai.

\section{KESIMPULAN DAN SARAN}

\section{Kesimpulan}

a. Hasil analisis deskriptif kualitatif tentang peran kepemimpinan, secara keseluruhan dapat dilihat bahwa rata-rata peran kepemimpinan di BKD Kota Pematangsiantar pada dimensi peranan interpersonal, peranan informasi dan peranan pengambil keputusan berada pada nilai rata-rata 4,02 dengan kriteria jawaban baik. Nilai rata-rata tertinggi ada pada dimensi peran pengambil keputusan dengan indikator wirausaha dengan nilai rata-rata 4,21 dengan kriteria jawaban sangat baik. Dan nilai rata-rata peran kepemimpinan terendah berada pada dimensi peran pengambil keputusan dengan indikator negosiator dengan nilai rata-rata 3,72 dengan kriteria jawaban baik.

b. Hasil analisis deskriptif kualitatif tentang kerjasama tim, secara keseluruhan dapat dilihat bahwa rata-rata kerjasama tim di BKD Kota Pematangsiantar pada dimensi lingkungan, peran, tujuan, dan masalah tim berada pada nilai ratarata 3,63 dengan kriteria jawaban baik. Nilai ratarata kerjasama tim tertinggi ada pada dimensi masalah tim dengan indikator pemecahan masalah berada pada nilai rata-rata 4,28 dengan kriteria jawaban sangat baik. Dan nilai rata-rata terendah berada pada dimensi lingkungan dengan indikator suportifitas, kerjasama dan rasa saling percaya berada pada nilai rata-rata yaitu 2,74 dengan kriteria jawaban cukup baik.

c. Hasil analisis deskriptif kualitatif tentang kinerja pegawai pada BKD Kota Pematangsiantar, secara keseluruhan nilai kinerja pegawai memiliki nilai rata-rata 4,06 dengan kriteria jawaban baik. Nilai jawaban responden tertinggi berada pada dimensi SKP dengan indikator tanggungjawab dengan nilai rata-rata 4,37 dengan kriteria jawaban sangat baik. Sedangkan nilai jawaban responden terendah berada pada dimensi perilaku kerja dengan indikator loyalitas berada pada nilai ratarata 3,74 dengan kriteria jawaban baik.

d. Hasil analisis linier berganda diperoleh persamaan sebagai berikut $\hat{Y}=24,495+0,395$ $\mathrm{X}_{1}+0,991 \mathrm{X}_{2}$ yang artinya terdapat pengaruh yang positif antara peran kepemimpinan dan kerjasama tim terhadap kinerja pegawai pada BKD Kota Pematangsiantar. e. Hasil analisis koefisien korelasi diperoleh nilai $r$ $=0,793$, artinya terdapat hubungan yang kuat antara antara peran kepemimpinan dan kerjasama tim dengan kinerja pegawai pada BKD Kota Pematangsiantar. Kemudian diperoleh nilai koefisien determinasi (R Square) $=0,628$, artinya tinggi rendahnya kinerja pegawai pada BKD Kota Pematangsiantar sebesar 62,8\% dapat dijelaskan oleh peran kepemimpinan dan kerjasama tim, sedangkan sisanya sebesar 37,2\% dipengaruhi oleh faktor lain seperti motivasi, kompensasi, pengembangan karir, dan dukungan manajemen yang tidak dibahas dalam penelitian ini.

f. Hasil pengujian hipotesis secara simultan dengan uji $\mathrm{F}$ diperoleh nilai $\mathrm{F}_{\text {hitung }}$ sebesar 33,786 $>\mathrm{F}_{\text {tabel }}$ dengan $(0,05 ; 2$ vs $(43-2-1=40))$ sebesar 3,23, atau dengan taraf signifikan $0,000<\alpha 0,05$, maka $\mathrm{H}_{0}$ ditolak, artinya peran kepemimpinan dan kerjasama tim berpengaruh positif dan signifikan terhadap kinerja pegawai pada BKD Kota Pematangsiantar.

g. Hasil pengujian hipotesis secara parsial dengan uji $\mathrm{t}$ diperoleh nilai $\mathrm{t}_{\text {hitung }}$ pada variabel peran kepemimpinan sebesar $2,572>\mathrm{t}_{\text {tabel }}$ dengan $\mathrm{df}=$ n-k-1 $(43-2-1=40)$ sebesar 2,021, atau dengan taraf signifikansi $0,014<\alpha 0,05$, maka $\mathrm{H}_{0}$ ditolak artinya peran kepemimpinan berpengaruh positif dan signifikan terhadap kinerja pegawai pada BKD Kota Pematangsiantar. Kemudian nilai $\mathrm{t}_{\text {hihtung }}$ pada kerjasama tim sebesar $6,497>\mathrm{t}_{\text {tabel }}$ dengan $\mathrm{df}=\mathrm{n}-\mathrm{k}-1(43-2-1=40)$ sebesar 2,021, atau dengan taraf signifikan $0,000<\alpha 0,05$, maka $\mathrm{H}_{0}$ ditolak artinya kerjasama tim berpengaruh positif dan signifikan terhadap kinerja pegawai pada BKD Kota Pematangsiantar.

\section{Saran}

a. Untuk meningkatkan peran kepemimpinan pada BKD Kota Pematangsiantar maka pimpinan BKD Kota Pematangsiantar mempererat hubungan kekeluargaan dengan para pegawai melalui terlebih dahulu mengenal setiap pegawai baik nama, latar belakang pendidikan dan sangat baik apabila pemimpin juga bisa melihat talenta dan kemampuan para bawahannya.

b. Untuk meningkatkan kerjasama tim pada BKD Kota Pematangsiantar maka pimpinan perlu melakukan komunikasi yang baik oleh pimpinan kepada pegawai, seperti memberi kesempatan kepada pegawai untuk menyampaikan pernyataannya, dan menunjukkan perhatian kepada pegawai, bahwa informasi yang diterima adalah penting sebagai kontribusi bagi kemajuan organisasi

c. Untuk meningkatkan kinerja pada BKD Kota Pematangsiantar, maka organisasi perlu meningkatkan kerapian hasil pekerjaan pegawai dengan cara atasan langsung pegawai selalu memeriksa hasil pekerjaan dan lebih menguasai tugas-tugas pokok kepegawaian dibanding bawahannya dan bukan sebaliknya. Dengan kemampuan pemimpin yang menguasai 
pekerjaan makan hasil kerja para bawahannya akan lebih optimal..

d. Sehubungan dengan keterbatasan-keterbatasan yang ada pada penulis, penelitian ini masih terdapat kelemahan-kelemahan dan belum dapat mengungkap seluruh variabel yang dapat mempengaruhi kinerja pegawai pada BKD Kota Pematangsiantar. Sebagai bahan masukan untuk penelitian selanjutnya, perlu memperbanyak variabel penelitian, seperti motivasi, kompetensi, kompensasi, pengembangan karir dan prestasi kerja yang tidak dibahas dalam penelitian ini.

\section{E. DAFTAR PUSTAKA}

Daft, Richard L.2007. Manajemen. Edisi Keenam. Jakarta: Salemba Empat

Ghozali, Imam. 2016. Aplikasi Analisis Multivariate dengan Program IBM SPSS 21. Semarang: Badan Penerbit Universitas Diponegoro.

Handoko, T Hani. 2012. Manajemen Sumber Daya Manusia. Edisi Kedua. Penerbit BPFE.Yogyakarta

Kartono, Kartini.2006. Pemimpin dan Kepemimpinan, Jakarta: Rajawali Pers.

Kreitner, Robert dan Angelo Kinicki. 2014. Perilaku Organisasi. Edisi Kesembilan. Jakarta Selatan. Penerbit Salemba Empat.

Mangkunegara, A. A. Anwar Prabu. 2009. Manajemen Sumber Daya Manusia.

Mathis, Robert L. dan John H. Jackson, 2006. Manajemen Sumber Daya Manusia. Jakarta: Salemba Empat Bandung: PT. Remaja Rosdakarya.
Mondy, Wayne R. 2008. Manajemen Sumber Daya Manusia. Cetakan Kedua. Bogor: Ghalia Indonesia.

Peraturan Pemerintah Nomor 46 Tahun 2011 tentang Penilaian Prestasi Kerja Pegawai Negeri Sipil.

Perka BKN No. 1 Tahun 2013 tentang Ketentuan Pelaksanaan Peraturan Pemerintah Nomor 46 Tahun 2011 tentang Penilaian Prestasi Kerja Pegawai Negeri Sipil

Robbins, Stephen P. dan Timothy A. Judge. 2008. Perilaku Organisasi. Edisi kesebelas. Jakarta: Salemba Empat.

Samsudin, H Sadili. 2010. Manajemen Sumber Daya Manusia. Bandung: Penerbit. Pustaka Setia

Sutrisno, Edy. 2009. Manajemen Sumber Daya Manusia Edisi Pertama Cetakan Pertama. Jakarta : Penerbit Kencana Prenada Media Group.

Sugiyono. 2010. Metode Penelitian Kuantitatif Kualitatif dan R\&D. Bandung: CV Alfabeta.

2012. Metode Penelitian Kuantitatif Kualitatif Dan R\&D. cetakan ke-17. Bandung: CV Alfabeta. 2013. Metode Penelitian Kuantitatif

Kualitatif Dan R\&D. Bandung: CV Alfabeta.

Wahyudi, Bambang. 2010. Manajemen Sumber Daya Manusia. Jakarta: Sulita. 